\title{
Understanding the Behaviour of Molecular Weight Fractions of Natural Organic Matter to Improve Water Treatment Processes
}

\author{
I. Kristiana*, B. P. Allpike*, C. A. Joll*, A. Heitz*, and R. Trolio** \\ * Curtin Water Quality Research Centre, Department of Applied Chemistry, Curtin University of Technology, \\ Kent Street, Bentley, WA 6102, Australia \\ (E-mail: I.Kristiana@curtin.edu.au) \\ ** Water Corporation of Western Australia, 629 Newcastle Street, Leederville, WA 6007, Australia
}

\begin{abstract}
Water utilities have experienced increasing pressure to minimise the formation of disinfection byproducts (DBPs), as reflected in the increasingly stringent regulations and guidelines for the concentrations of DBPs in drinking water. Understanding the disinfection characteristics and molecular weight (MW) distribution of natural organic matter (NOM) will assist in the optimisation of drinking water treatment processes to minimise the formation of DBPs. This study investigated the disinfection behaviour of MW fractions of NOM isolated from a Western Australian source water. The NOM was fractionated and separated using preparative size exclusion chromatography (SEC) and the fractions were chlorinated in the presence of bromide ion. The larger MW fractions of NOM were found to produce the highest concentrations of DBPs (trihalomethanes, haloacetic acids, haloacetonitriles, haloketones, and haloaldehydes), with the low MW fractions still producing significant amounts of these DBPs. The results also showed a trend of an increasing proportion of brominated DBPs with decreasing MW and aromatic character. Considering that the smaller MW fractions of NOM produce significant amounts of DBPs, with a higher relative contribution from brominated DBPs, water treatment processes need to be optimised for either bromide removal or the removal of aliphatic, small MW fractions of NOM, in order to meet DBP guidelines and regulations.
\end{abstract}

Keywords

Disinfection by-products, molecular weight, natural organic matter, size exclusion chromatography, trihalomethanes, water treatment

\section{INTRODUCTION}

Natural organic matter (NOM) is an extremely complex mixture of organic compounds, which have been reported to exist mainly as macromolecules, in the form of large, polymeric-type structures (Croué et al., 1999). Removal of NOM from source waters is often required in order to produce drinking water that is microbiologically and chemically safe. Knowledge of the molecular weight (MW) distribution of NOM is of importance in drinking water treatment process operations. For example, previous research has demonstrated that low MW NOM components compete with target compounds for adsorption sites on activated carbon, thus reducing the efficiency of activated carbon treatment (Newcombe et al., 1997). Low MW compounds have been associated with the fraction that is the most difficult to remove using conventional coagulation treatment (Chow et al., 1999; Drikas et al., 2003). The MW distribution of NOM has also been shown to be a significant factor in the fouling of membranes used in drinking water treatment (Aoustin et al., 2001). Some studies have shown that the low MW fractions contribute significantly to bioavailable organic matter (BOM), which is responsible for bacterial regrowth and biofilm formation in distribution systems (Hem and Efraimsen, 2001). Different MW components of NOM have been shown to have different specific yields of the various types of disinfection by-products (DBPs). Hua and Reckhow (2007) reported that NOM with MW between 0.5 and $3 \mathrm{kDa}$ produced the highest trihalomethanes (THM) yield among all MW fractions studied, while other reports have indicated that the larger MW fractions of NOM (>1 kDa) contain the more reactive THM precursors (Chow et al., 2005 and 
references therein). Hua and Reckhow (2007) also reported that the low MW NOM fractions $(<0.5$ $\mathrm{kDa}$ ) contained more abundant dichloroacetic acid precursors than the other MW fractions studied.

Epidemiological studies have associated DBPs with a number of adverse human health effects, e.g. cancers of the urinary and digestive tracts, bladder and colon cancers, low birth weight, intrauterine growth retardation, and spontaneous abortion (e.g. Richardson et al., 2007; Villanueva et al., 2007; Nieuwenhuijsen et al., 2000), although some of these effects are still controversial and require further study. Recent findings have also shown that brominated and iodinated DBPs are significantly more toxic than their chlorinated analogues (Richardson et al., 2007; Plewa et al., 2004). Nitrogen-containing DBPs, such as the haloacetonitriles and $N$-nitrosamines, have also been reported to present greater toxicological concerns than the regulated DBPs (Bull, 2003). Due to the potential adverse human health effects associated with DBPs, in many countries the concentrations of some DBPs in drinking waters are regulated. Recent changes in international standards for drinking water quality have involved a reduction in health guideline values for the currently regulated DBPs, resulting in increasing pressure for water utilities to balance the competing requirements of maintaining effective disinfection $v s$. control of DBP concentrations in disinfection practices. The removal of DBP precursors, e.g. NOM, prior to disinfection and distribution has been shown to be the most effective approach to minimise the formation of DBPs. In order to achieve efficient removal of DBP precursors, a good understanding of the characteristics of NOM, such as its MW distribution, is needed.

Size exclusion chromatography (SEC) is commonly used to determine the MW distribution of NOM. It is a separation method based on the hydrodynamic molecular size of the material being analysed (Pelekani et al., 1999). In the chromatography column, small molecules can access more of the internal pore volume than larger molecules, thus, ideally, larger molecules are excluded from the pores and elute first, followed by smaller components (Pelekani et al., 1999). The attractiveness of this method is due to its ease of operation, minimal sample pre-treatment, and speed of analysis. SEC can be done at an analytical or preparative scale. Preparative SEC allows the isolation of highly resolved organic rich MW fractions of NOM through repeated injection of the water sample onto a preparative scale column, followed by collection of each fraction (Peuravuori and Pihlaja, 2004). Preparative scale sample volumes and column sizes are typically much larger than those used for analytical SEC, but comparable separation of components can be achieved, allowing direct comparison between the analytical scale results and fractions obtained using the preparative system.

In the current study, preparative SEC, automated by use of a large volume autosampler and a stateof-the-art fraction collector, was used to isolate MW fractions of NOM from a local surface water source. Sufficient NOM in each MW fraction was isolated to allow the disinfection behaviour of the collected fractions to be investigated, in order to determine the potential of each MW fraction to form a range of DBPs.

\section{METHODS}

\section{Preparation of Molecular Weight Fractions of NOM}

A local surface water source (dissolved organic carbon concentration (DOC) $=26.2 \mathrm{mg} \mathrm{L}^{-1}$ ) was collected $(1000 \mathrm{~L})$ and filtered through a $0.45 \mu \mathrm{m}$ membrane, and then subjected to reverse osmosis (RO) to concentrate the organic matter in the sample. The final volume of RO concentrate was $16 \mathrm{~L}$ and the DOC concentration in the concentrate was approximately $1200 \mathrm{mg} \mathrm{L}^{-1}$. A portion of this RO concentrate was then subjected to preparative SEC, following the method described by Peuravuori and Pihlaja (2004). The high pressure liquid chromatography (HPLC) system was an Agilent 1100 
equipped with a dual-loop autosampler, a diode array detector collecting data at $254 \mathrm{~nm}$, and an automated fraction collector. The eluent comprised a $20 \mathrm{mM}$ phosphate buffer with a flow rate of 4 $\mathrm{mL} \mathrm{min}^{-1}$ and the injection volume was $1 \mathrm{~mL}$. Separation of NOM was achieved using a BioSepSEC-S 3000 (300 x 21.2 mm i.d., Phenomenex) column, which was preceded by a BioSep SEC-S 3000 guard column (75 x $21.2 \mathrm{~mm}$ i.d., Phenomenex). Eight individual fractions were collected, with an additional blank fraction at the start of the chromatogram. The large volumes of each separated fraction, also containing the HPSEC phosphate mobile phase, were concentrated to approximately $1 \mathrm{~L}$ by reduced pressure distillation and desalted by ultrafiltration.

\section{Chemicals and Reagents}

All chemicals, reagents, and organic solvents used in this study were of analytical grade purity (AR grade $\geq 99 \%$ pure) or better, and were used without further purification.

\section{NOM Characterisation}

The MW fractions of NOM were analysed for $\mathrm{UV}_{254}$ absorbance and DOC concentration. The $\mathrm{UV}_{254}$ absorbance of the samples was determined using a HP 8452A Diode Array Spectrophotometer with a $5 \mathrm{~cm}$ quartz cell. The DOC concentration of the samples was determined by the UV/persulfate oxidation method, using a Shimadzu TOC Analyser TOC- $\mathrm{V}_{\text {ws. }}$

\section{Disinfection Experiments}

The MW fractions (each diluted with MilliQ water to an identical DOC concentration of $2 \mathrm{mg} \mathrm{L}^{-1}$ ) were each subjected to chlorination $\left(8 \mathrm{mg} \mathrm{L}^{-1} \mathrm{Cl}_{2}\right)$ in the presence of bromide ion $\left(0.5 \mathrm{mg} \mathrm{L}^{-1}\right)$. The experiments were carried out at $20^{\circ} \mathrm{C}$, for 72 hours, at $\mathrm{pH} 7$ (buffered using phosphate buffer). In each experiment, at various times up to $72 \mathrm{hr}$, the residual chlorine in a subsample of the reaction solution was quenched with aqueous sodium sulfite solution or ascorbic acid solution, and the sample was then analysed for DBPs.

\section{Analysis of DBPs}

Chlorinated samples of the NOM fractions were analysed for a range of DBPs, listed in Table 1. THMs were extracted from the samples using solid-phase microextraction in the headspace mode, and analysed using gas chromatography with mass spectrometric detection (HS SPME/GC-MS). HAAs were analysed using a modified EPA Method 552.3, which involves liquid-liquid extraction of the acids with methyl tert-butyl ether (MTBE) as solvent, followed by derivatisation of the acids into their corresponding methyl esters using acidic methanol, and subsequent analysis of the HAA methyl esters by GC-MS. Haloacetonitriles, haloketones, haloaldehydes, and chloropicrin were extracted from the samples using liquid-liquid extraction with MTBE as solvent, and analysed by GC-MS. The GC-MS system used for the analysis of these DBPs was a Hewlett Packard 6980N GC interfaced to Hewett Packard 5973Network Mass Selective Detector, equipped with a $60 \mathrm{~m}$ x 0.25 mm ID ZB-5 (Phenomenex) column with a film thickness of $1 \mu \mathrm{m}$.

Table 1. List of DBPs analysed

\begin{tabular}{ll}
\hline DBP Group & DBP Species \\
\hline Trihalomethanes & $\mathrm{CHCl}_{3}$ \\
(THMs) & $\mathrm{CHCl}_{2} \mathrm{Br}$ \\
& $\mathrm{CHClBr}_{2}$ \\
& $\mathrm{CHBr}_{3}$ \\
\hline Haloacetic acids & Chloroacetic acid (MCAA) \\
(HAAs) & Dichloroacetic acid (DCAA) \\
& Trichloroacetic acid (TCAA) \\
& Bromoacetic acid (MBAA) \\
& Dibromoacetic acid (DBAA) \\
& Tribromoacetic acid (TBAA) \\
\hline
\end{tabular}




\begin{tabular}{|c|c|}
\hline & $\begin{array}{l}\text { Bromochloroacetic acid (BCAA) } \\
\text { Bromodichloroacetic acid (BDCAA) } \\
\text { Chlorodibromoacetic acid (CDBAA) }\end{array}$ \\
\hline $\begin{array}{l}\text { Haloacetonitriles } \\
\text { (HANs) }\end{array}$ & $\begin{array}{l}\text { Chloroacetonitrile (MCAN) } \\
\text { Dichloroacetonitrile (DCAN) } \\
\text { Trichloroacetonitrile (TCAN) } \\
\text { Bromochloroacetonitrile (BCAN) } \\
\text { Dibromoacetonitrile (DBAN) }\end{array}$ \\
\hline $\begin{array}{l}\text { Haloketones } \\
(\mathrm{HKs})\end{array}$ & $\begin{array}{l}\text { Chloropropanone (Cl-propanone) } \\
\text { Dichloropropanone }\left(\mathrm{Cl}_{2} \text {-propanone }\right) \\
\text { Trichloropropanone }\left(\mathrm{Cl}_{3} \text {-propanone }\right) \\
\text { Dibromochloropropanone }\left(\mathrm{Br}_{2} \mathrm{Cl} \text {-propanone }\right) \\
\text { Dibromopropanone }\left(\mathrm{Br}_{2} \text {-propanone }\right)\end{array}$ \\
\hline $\begin{array}{l}\text { Haloaldehydes } \\
\text { (HALs) }\end{array}$ & $\begin{array}{l}\text { Trichloroacetaldehyde }\left(\mathrm{Cl}_{3}-\mathrm{AL}\right) \\
\text { Bromochloroacetaldehyde }(\mathrm{BrCl}-\mathrm{AL}) \\
\text { Bromodichloroacetaldehyde }\left(\mathrm{BrCl}_{2}-\mathrm{AL}\right) \\
\text { Dibromoacetaldehyde }\left(\mathrm{Br}_{2}-\mathrm{AL}\right) \\
\text { Tribromoacetaldehyde }\left(\mathrm{Br}_{3}-\mathrm{AL}\right)\end{array}$ \\
\hline Halonitromethanes & Chloropicrin \\
\hline
\end{tabular}

\section{RESULTS AND DISCUSSION}

Eight apparent MW fractions of NOM and a blank fraction (Fraction 1) were collected from a Western Australian surface water source using a preparative SEC method. Table 2 shows the apparent MW ranges of the collected fractions, together with the $\mathrm{SUVA}_{254}$ values of each fraction. These fractions, with the DOC concentrations normalised to $2 \mathrm{mg} \mathrm{L}^{-1}$, were separately chlorinated in the presence of bromide ion and some of the DBPs formed (Table 1) were analysed over a 72hour period.

Table 2. Apparent molecular weight range of collected fractions of local surface water NOM

\begin{tabular}{ccc}
\hline Fraction \# & Apparent MW range & SUVA $_{\mathbf{2 5 4}}\left(\mathbf{L} \mathbf{~ m g}^{-\mathbf{1}} \mathbf{~ m}^{-\mathbf{1}}\right)$ \\
\hline 1 & Blank & N/A \\
2 & $>20 \mathrm{kDa}$ & 3 \\
3 & $5-20 \mathrm{kDa}$ & 6.3 \\
4 & $3-5 \mathrm{kDa}$ & 5.2 \\
5 & $2.5-3 \mathrm{kDa}$ & 5.2 \\
6 & $2-2.5 \mathrm{kDa}$ & 5.0 \\
7 & $1.5-2 \mathrm{kDa}$ & 4.4 \\
8 & $1-1.5 \mathrm{kDa}$ & 4.3 \\
9 & $0.3-1 \mathrm{kDa}$ & 3.3 \\
\hline
\end{tabular}

\section{Formation of DBPs}

Table 3 presents the mass and molar concentrations of DBPs measured in the chlorinated NOM fractions at the end of the experimental period. Since the initial DOC concentrations were the same $\left(2 \mathrm{mg} \mathrm{L}^{-1}\right)$ for all fractions, these concentrations are equivalent to twice the specific yields of these analytes. The formation of DBPs in Fraction 1 was negligible, as it was a blank fraction, and thus this data is not presented here. The data presented in Table 3 shows that Fraction 2 produced the highest mass and molar concentrations of total HANs, while Fraction 3 produced the highest mass and molar concentrations of total HAAs, and Fraction 4 produced the highest mass and molar concentrations of total THMs. These trends show that the medium to large MW fractions of NOM produced the highest concentrations of DBPs. However, the low MW fractions still produced significant amounts of DBPs, with fractions having apparent MW less than $2 \mathrm{kDa}$ producing 37\% (based on molar DBP concentrations) of the total DBPs measured. 
Table 3. The mass and molar concentrations of DBPs formed from the chlorinated NOM fractions $(\mathrm{t}=72 \mathrm{hr})$

\begin{tabular}{|c|c|c|c|c|c|c|c|c|}
\hline \multirow[t]{2}{*}{ DBPs } & \multicolumn{8}{|c|}{ Concentration } \\
\hline & $\begin{array}{c}\text { Fraction } \\
2\end{array}$ & $\begin{array}{c}\text { Fraction } \\
3\end{array}$ & $\begin{array}{c}\text { Fraction } \\
4\end{array}$ & $\begin{array}{c}\text { Fraction } \\
5\end{array}$ & $\begin{array}{c}\text { Fraction } \\
6\end{array}$ & $\begin{array}{c}\text { Fraction } \\
7\end{array}$ & $\begin{array}{c}\text { Fraction } \\
8\end{array}$ & $\begin{array}{c}\text { Fraction } \\
9\end{array}$ \\
\hline \multicolumn{9}{|l|}{ THMs } \\
\hline $\mathrm{CHCl}_{3}\left(\mu \mathrm{g} \mathrm{L}^{-1}\right)$ & $<0.4$ & 16 & 22 & 24 & 22 & 14 & 14 & 5 \\
\hline $\mathrm{CHBrCl}_{2}\left(\mu \mathrm{g} \mathrm{L}^{-1}\right)$ & 9 & 74 & 100 & 97 & 94 & 82 & 79 & 54 \\
\hline $\mathrm{CHBr}_{2} \mathrm{Cl}\left(\mu \mathrm{g} \mathrm{L}^{-1}\right)$ & 77 & 140 & 184 & 174 & 165 & 165 & 157 & 142 \\
\hline $\mathrm{CHBr}_{3}\left(\mu \mathrm{g} \mathrm{L}^{-1}\right)$ & 68 & 46 & 69 & 64 & 61 & 72 & 66 & 83 \\
\hline Total $\left(\mu \mathrm{g} \mathrm{L}^{-1}\right)$ & 154 & 276 & 375 & 359 & 342 & 333 & 316 & 284 \\
\hline Total $(\mu \mathrm{M})$ & 0.70 & 1.44 & 1.96 & 1.88 & 1.80 & 1.70 & 1.62 & 1.38 \\
\hline \multicolumn{9}{|l|}{ HAAs } \\
\hline $\operatorname{MCAA}\left(\mu \mathrm{g} \mathrm{L}{ }^{-1}\right)$ & $<3$ & $<3$ & $<3$ & $<3$ & $<3$ & $<3$ & $<3$ & $<3$ \\
\hline $\operatorname{MBAA}\left(\mu \mathrm{g} \mathrm{L}^{-1}\right)$ & $<2$ & $<2$ & $<2$ & $<2$ & $<2$ & $<2$ & $<2$ & $<2$ \\
\hline DCAA $\left(\mu \mathrm{g} \mathrm{L}^{-1}\right)$ & 16 & 41 & 31 & 28 & 21 & 20 & 19 & 22 \\
\hline DBAA $\left(\mu \mathrm{g} \mathrm{L}^{-1}\right)$ & 3 & 12 & 7 & 6 & 5 & 4 & 4 & 5 \\
\hline $\mathrm{BCAA}\left(\mu \mathrm{g} \mathrm{L}^{-1}\right)$ & 10 & 26 & 18 & 16 & 12 & 11 & 11 & 12 \\
\hline TCAA $\left(\mu \mathrm{g} \mathrm{L}^{-1}\right)$ & 26 & 56 & 43 & 42 & 35 & 27 & 28 & 33 \\
\hline TBAA $\left(\mu \mathrm{g} \mathrm{L}^{-1}\right)$ & $<3.8$ & $<3.8$ & $<3.8$ & $<3.8$ & $<3.8$ & $<3.8$ & $<3.8$ & $<3.8$ \\
\hline $\operatorname{BDCAA}\left(\mu \mathrm{g} \mathrm{L}^{-1}\right)$ & 27 & 54 & 37 & 37 & 32 & 24 & 27 & 30 \\
\hline CDBAA $\left(\mu \mathrm{g} \mathrm{L}^{-1}\right)$ & $<3.2$ & $<3.2$ & $<3.2$ & $<3.2$ & $<3.2$ & $<3.2$ & $<3.2$ & $<3.2$ \\
\hline HAA5 $\left(\mu \mathrm{g} \mathrm{L}^{-1}\right)$ & 45 & 109 & 81 & 152 & 61 & 51 & 51 & 60 \\
\hline Total $\left(\mu \mathrm{g} \mathrm{L}^{-1}\right)$ & 82 & 189 & 136 & 129 & 105 & 86 & 89 & 102 \\
\hline Total $(\mu \mathrm{M})$ & 0.49 & 1.13 & 0.82 & 0.77 & 0.63 & 0.52 & 0.53 & 0.61 \\
\hline \multicolumn{9}{|l|}{ HANs } \\
\hline $\operatorname{MCAN}\left(\mu \mathrm{g} \mathrm{L}^{-1}\right)$ & $<1$ & $<1$ & $<1$ & $<1$ & $<1$ & $<1$ & $<1$ & $<1$ \\
\hline $\operatorname{DCAN}\left(\mu \mathrm{g} \mathrm{L}^{-1}\right)$ & $<0.5$ & $<0.5$ & $<0.5$ & $<0.5$ & $<0.5$ & $<0.5$ & $<0.5$ & $<0.5$ \\
\hline $\operatorname{DBAN}\left(\mu \mathrm{g} \mathrm{L}^{-1}\right)$ & 11 & 4.6 & 4.0 & 3.8 & 3.9 & 3.2 & 6.7 & 7.4 \\
\hline $\mathrm{BCAN}\left(\mu \mathrm{g} \mathrm{L}^{-1}\right)$ & $<0.2$ & $<0.2$ & $<0.2$ & $<0.2$ & $<0.2$ & $<0.2$ & $<0.2$ & $<0.2$ \\
\hline TCAN $\left(\mu \mathrm{g} \mathrm{L}^{-1}\right)$ & $<0.2$ & $<0.2$ & $<0.2$ & $<0.2$ & $<0.2$ & $<0.2$ & $<0.2$ & $<0.2$ \\
\hline Total $\left(\mu \mathrm{g} \mathrm{L}^{-1}\right)$ & 11 & 4.6 & 4.0 & 3.8 & 3.9 & 3.2 & 6.7 & 7.4 \\
\hline Total $(\mu \mathrm{M})$ & 0.056 & 0.023 & 0.020 & 0.019 & 0.019 & 0.016 & 0.034 & 0.037 \\
\hline \multicolumn{9}{|l|}{ HKs } \\
\hline Cl-propanone $\left(\mu \mathrm{g} \mathrm{L}^{-1}\right)$ & $<0.5$ & $<0.5$ & $<0.5$ & $<0.5$ & $<0.5$ & $<0.5$ & $<0.5$ & $<0.5$ \\
\hline $\mathrm{Cl}_{2}$-propanone $\left(\mu \mathrm{g} \mathrm{L}^{-1}\right)$ & $<1$ & $<1$ & $<1$ & $<1$ & $<1$ & $<1$ & $<1$ & $<1$ \\
\hline $\mathrm{Cl}_{3}$-propanone $\left(\mu \mathrm{g} \mathrm{L}^{-1}\right)$ & $<0.5$ & $<0.5$ & $<0.5$ & $<0.5$ & $<0.5$ & $<0.5$ & $<0.5$ & $<0.5$ \\
\hline $\mathrm{Br}_{2} \mathrm{Cl}$-propanone $\left(\mu \mathrm{g} \mathrm{L}^{-1}\right)$ & 3.1 & $<1$ & $<1$ & $<1$ & $<1$ & 1.6 & 1.8 & 1.7 \\
\hline $\mathrm{Br}_{2}$-propanone $\left(\mu \mathrm{g} \mathrm{L}^{-1}\right)$ & 8.7 & $<1$ & $<1$ & $<1$ & $<1$ & 2.2 & 2.2 & 2.2 \\
\hline Total $\left(\mu \mathrm{g} \mathrm{L}^{-1}\right)$ & 12 & -- & -- & -- & -- & 3.8 & 4.0 & 3.9 \\
\hline Total $(\mu \mathrm{M})$ & 0.051 & -- & -- & -- & -- & 0.014 & 0.018 & 0.017 \\
\hline \multicolumn{9}{|l|}{ HALs } \\
\hline $\mathrm{Cl}_{3}-\mathrm{AL}\left(\mu \mathrm{g} \mathrm{L}^{-1}\right)$ & 3.1 & 14 & 6.3 & 7.2 & 0.7 & 0.5 & $<0.2$ & $<0.2$ \\
\hline $\mathrm{BrCl}-\mathrm{AL}\left(\mu \mathrm{g} \mathrm{L}^{-1}\right)$ & 1.4 & $<0.5$ & $<0.5$ & $<0.5$ & $<0.5$ & $<0.5$ & 0.8 & $<\mathrm{DL}$ \\
\hline $\mathrm{BrCl}_{2}-\mathrm{AL}\left(\mu \mathrm{g} \mathrm{L}^{-1}\right)$ & 4.0 & 4.0 & 3.4 & 3.8 & 3.1 & 2.6 & 3.5 & 2.4 \\
\hline $\mathrm{Br}_{2}-\mathrm{AL}\left(\mu \mathrm{g} \mathrm{L}^{-1}\right)$ & $<1$ & $<1$ & $<1$ & $<1$ & $<1$ & $<1$ & $<1$ & $<1$ \\
\hline $\mathrm{Br}_{3}-\mathrm{AL}\left(\mu \mathrm{g} \mathrm{L}^{-1}\right)$ & $<5$ & $<5$ & $<5$ & $<5$ & $<5$ & $<5$ & $<5$ & $<5$ \\
\hline Total $\left(\mu \mathrm{g} \mathrm{L}^{-1}\right)$ & 8.5 & 18 & 9.7 & 11 & 3.8 & 3.1 & 4.3 & 2.4 \\
\hline Total $(\mu \mathrm{M})$ & 0.045 & 0.10 & 0.055 & 0.062 & 0.019 & 0.014 & 0.019 & 0.011 \\
\hline \multicolumn{9}{|c|}{ HALONITROMETHANES } \\
\hline Chloropicrin $\left(\mu \mathrm{g} \mathrm{L}^{-1}\right)$ & $<0.5$ & $<0.5$ & $<0.5$ & $<0.5$ & $<0.5$ & $<0.5$ & $<0.5$ & $<0.5$ \\
\hline
\end{tabular}

THMs and HAAs were the two major groups of DBPs observed in the chlorinated NOM fractions, comprising 86-98\% (based on molar DBP concentrations) of the total DBPs measured. This is consistent with previously reported studies that showed THMs and HAAs as the two largest classes of DBPs detected in chlorinated waters (e.g. Obolensky and Singer, 2005; Roberts et al., 2002). In all MW fractions of NOM, the total THM mass concentrations at the end of the experimental period 
exceeded the Australian Drinking Water Guideline (ADWG) value $\left(250 \mu \mathrm{g} \mathrm{L}^{-1}\right)$ and the US EPA regulation value $\left(80 \mu \mathrm{g} \mathrm{L}^{-1}\right)$, while the mass concentrations of HAA5 (total mass concentrations of MCAA, MBAA, DCAA, DBAA, and TCAA) in fractions 3, 4, 5, and 6 exceeded the US EPA regulation $\left(60 \mu \mathrm{g} \mathrm{L}^{-1}\right)$. This demonstrates the high reactivity of the NOM fractions for the formation of DBPs. In a separate laboratory-scale chlorination experiment (not reported here) of this surface water after alum coagulation (with powdered activated carbon added into the coagulation process) treatment, using similar experimental conditions to those reported in this paper, the total THM and total HAA concentrations after 72-hour reaction period were 180 and $85 \mu \mathrm{g} \mathrm{L}^{-1}$, respectively. While the total THM concentration did not exceed the ADWG value, the total THM and HAA concentrations exceeded the US EPA regulation values. This shows that, for this surface water, the fraction of NOM which was not removed by the treatment process was still reactive for the formation of DBPs.

The total THM concentrations (both molar and mass concentrations) were higher than those of the total HAAs for all fractions. Further examination of the data shows that the proportions of THMs in fractions 6, 7, and 8 were significantly higher than those of HAAs, compared to the other MW fractions. This demonstrates that, for this particular source water, NOM with apparent MW of 1 to $2.5 \mathrm{kDa}$ contains a higher proportion of THM precursors than HAA precursors. The relative distribution of HAAs and THMs is believed to be influenced by the hydrophobic/hydrophilic distribution of NOM (Liang and Singer, 2003). The hydrophilic fraction of NOM, which is rich in aliphatic structures, has been reported to be a more significant precursor of THMs, while HAA precursors have been found to be more hydrophobic and have higher aromatic content than THM precursors (Liang and Singer, 2003). The results from this study show that the size of NOM also influences the relative distribution of THMs and HAAs.

Minor contributions from HANs, HALs, and HKs were observed, with low concentrations of these DBPs measured in the samples (Table 3). Chloropicrin was not detected in any sample. Only one species of HAN, DBAN, was measured in the chlorinated samples. Other species of HANs may have been present at concentrations below the detection limits of the analytical method for the determination of HANs. Reckhow and Singer (1990) reported that dihaloacetonitriles are the most common species of HAN detected in various water samples. As a result of the high concentration of bromide ion in the samples, the formation of DBAN seemed to be favoured over DCAN.

The extent of the formation of DBPs were found to vary for different groups of DBPs. Figure 1 shows the total mass concentrations of the different groups of DBPs from each MW fraction over the experimental period. DBP formation generally increased with increasing reaction time, however, in some cases, similar concentrations were observed at $\mathrm{t}=24 \mathrm{hr}$ and $\mathrm{t}=72 \mathrm{hr}$. This may indicate that there was no further formation of that particular DBP after 24 hours, suggesting a limited amount of precursor sites that could react with the excess chlorine and bromine to form DBPs. This plateau effect can be seen in the production of THMs from Fractions 2 and 9; the production of HAAs from Fractions 2 to 8; the production of HANs from Fractions 3, 4, and 8; and the production of HALs from Fractions 6 to 9. Furthermore, the production of HANs and HKs from some MW fractions was found to decrease over time, indicating possible degradation of the DBPs produced. This can be seen in the production of HANs from Fractions 5, 6, 7, and 9; and in the production of HKs from all MW fractions. HANs and HKs have been reported to be intermediate compounds to HAAs and THMs, respectively (Glezer et al., 1999; Krasner, 1999). Thus, it was likely that some HANs and HKs were degraded to their corresponding HAAs and THMs over the experimental period, resulting in a decreasing trend in their concentrations over time. The data obtained in this study show that the concentrations of DBPs can vary over time as a result of the continued formation of DBPs in the presence of chlorine, bromine, and precursor materials, as well 
as due to the degradation of some DBP species. These factors must therefore be considered in the evaluation of DBP exposure.
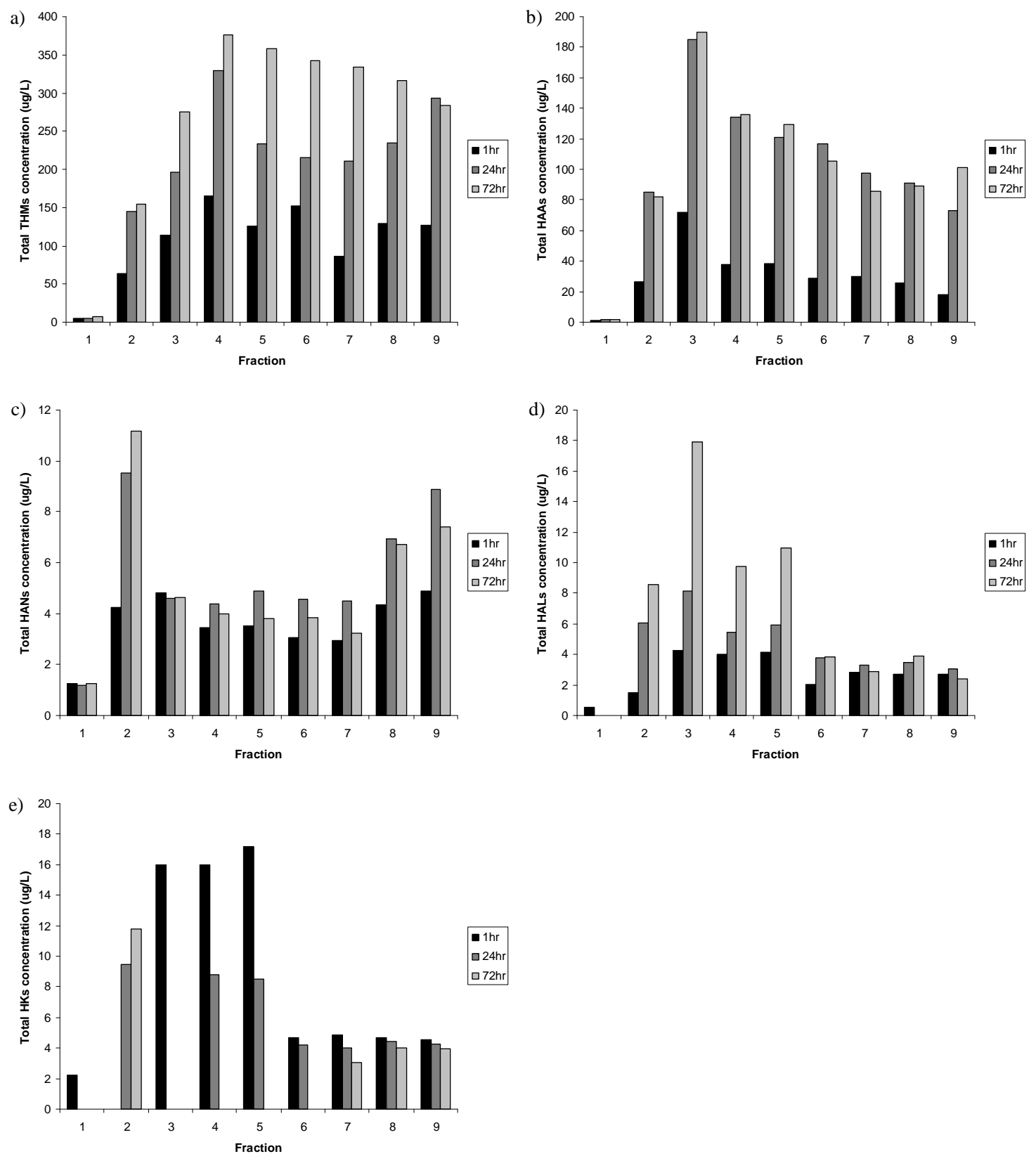

Figure 1. a) Concentrations of total THMs b) Concentrations of total HAAs c) Concentrations of total HANs d) Concentrations of total HALs, and e) Concentrations of total HKs in chlorinated apparent MW fractions of NOM over the 72-hr experimental period

\section{Halogen Incorporation into DBPs}

The species distribution of DBPs observed (Table 3) reflects the high initial bromide ion concentration in the samples. Regardless of MW, the MW fractions of NOM tended to form higher concentrations of bromine-containing DBPs than chlorine-only containing DBPs. All four species of THMs were detected. Only five out of the nine species of HAAs were detected. These were DCAA, TCAA, BCAA, DBAA, and BDCAA, three of which contain bromine. DBAN was the only $\mathrm{HAN}$ detected and two brominated species of $\mathrm{HKs}\left(\mathrm{Br}_{2} \mathrm{Cl}\right.$-propanone and $\mathrm{Br}_{2}$-propanone) were the only $\mathrm{HKs}$ detected. Out of the three species of HALs detected $\left(\mathrm{Cl}_{3}-\mathrm{AL}, \mathrm{BrCl}-\mathrm{AL}\right.$, and $\left.\mathrm{BrCl}_{2}-\mathrm{AL}\right)$, two of them contain bromine. 
The amount of chlorine and bromine incorporated into the measured DBPs in each MW fraction of NOM in this study (i.e. the total number of moles of bromine and chlorine contained in the measured DBPs), along with the mole ratio of bromine to chlorine, are presented in Table 4 . The $\%$ halogen incorporation into the measured DBPs (\% halogen incorporation $=$ total number of moles of halogen incorporated into DBPs / initial number of moles of halogen) is also given in Table 4. Overall, a significantly higher proportion of bromine was incorporated into the measured DBPs than chlorine. Only $0.7-2 \%$ of the initial chlorine present in the sample was incorporated into the measured DBPs, while up to $58 \%$ of the initial bromide ion was incorporated into the measured DBPs. Previous studies of chlorination of source waters and solutions of NOM in the presence of bromide have also showed that bromine incorporation into NOM is favoured over chlorine, even when chlorine is present in large excess compared to bromide ion concentration, resulting in higher percentages of bromine compared to chlorine incorporated into DBPs (e.g. Westerhoff et al., 2004). These observations can be explained in terms of the physical and chemical characteristics of chlorine and bromine species present, and the chemical reactions involving these species. In a chlorinated system, chlorine (mostly present as $\mathrm{HOCl}$ at $\mathrm{pH} 6-8$ ) reacts with organic and inorganic materials in solution through various reaction pathways, where chlorine is acting primarily as an oxidant or as an electrophile. When bromide ion is present, it is readily oxidised to $\mathrm{HOBr}$ by chlorine. $\mathrm{HOCl}$ has a higher redox potential than $\mathrm{HOBr}\left(\mathrm{E}_{\mathrm{HOCl}}^{\mathrm{O}}=1.63 \mathrm{~V} ; \mathrm{E}_{\mathrm{HOBr}}^{\mathrm{o}}=1.33 \mathrm{~V}\right)$, but the bromine atom has a higher electron density (Westerhoff et al., 2004), and $\mathrm{HOBr}$ is a stronger electrophile than $\mathrm{HOCl}$ (Ichihashi et al., 1998). Therefore, $\mathrm{HOBr}$ is a better halogenating agent than $\mathrm{HOCl}$, and incorporation of bromine into NOM is therefore favoured over chlorine incorporation. In addition, the recycling of bromide through oxidation reactions has been reported to increase bromine incorporation into NOM (Sweetman and Simmons, 1980). In the bromide recycling process, some $\mathrm{HOBr}$ may participate in oxidation reactions that do not involve the incorporation of bromine into NOM, producing bromide. This bromide can then be re-oxidised to $\mathrm{HOBr}$ again by $\mathrm{HOCl}$. Thus, $1 \mathrm{~mol}$ of bromide can potentially consume more than $1 \mathrm{~mol}$ of $\mathrm{HOCl}$, and this process may continue as long as $\mathrm{HOCl}$ remains in the system, and until stable reaction products are formed (Sweetman and Simmons, 1980). In contrast, chloride produced from redox reactions between $\mathrm{HOCl}$ and NOM cannot be re-oxidised. This recycling of bromide can contribute to higher bromine incorporation into NOM.

Table 4. Extent of halogen incorporation in chlorinated MW fractions of NOM

\begin{tabular}{lccccc}
\hline NOM & \multicolumn{2}{c}{$\begin{array}{c}\text { Amount Incorporated } \\
\text { into DBPs }(\boldsymbol{\mu m o l})\end{array}$} & $\begin{array}{c}\text { Br/Cl ratio } \\
{[\mathbf{n}(\mathbf{B r}) /}\end{array}$ & \multicolumn{2}{c}{$\begin{array}{c}\text { \% Halogen } \\
\text { Incorporation }\end{array}$} \\
\cline { 2 - 3 } & $\mathbf{C l}$ & $\mathbf{B r}$ & $\mathbf{C l})]$ & $\mathbf{C l}$ & $\mathbf{B r}$ \\
\hline Fraction 2 & 1.64 & 2.07 & 1.3 & 0.7 & 33 \\
Fraction 3 & 4.63 & 2.92 & 0.6 & 2.0 & 47 \\
Fraction 4 & 4.53 & 3.60 & 0.8 & 2.0 & 58 \\
Fraction 5 & 4.44 & 3.40 & 0.8 & 2.0 & 54 \\
Fraction 6 & 2.65 & 1.77 & 0.7 & 1.2 & 28 \\
Fraction 7 & 3.30 & 3.22 & 1.0 & 1.5 & 52 \\
Fraction 8 & 3.26 & 3.13 & 1.0 & 1.4 & 50 \\
Fraction 9 & 3.22 & 3.42 & 1.0 & 1.4 & 55 \\
\hline
\end{tabular}

The extent of bromine incorporation into the measured DBPs in each MW fraction can be evaluated using the $\mathrm{Br} / \mathrm{Cl}$ mole ratios (Table 4). Although significantly higher proportion of bromine was incorporated into the measured DBPs than chlorine, the number of moles of bromine and chlorine incorporated into the measured DBPs were similar. This results in $\mathrm{Br} / \mathrm{Cl}$ mole ratios that are close to 1 for all $\mathrm{MW}$ fractions. Overall, there was a tendency for increasing $\mathrm{Br} / \mathrm{Cl}$ ratio with decreasing $\mathrm{MW}$. $\mathrm{Br} / \mathrm{Cl}$ ratios for Fractions 7 to 9 were higher than those for Fractions 3 to 6 . This suggests that bromine is more likely to be incorporated into DBPs produced from smaller MW fractions of NOM. 
Comparison of the $\mathrm{Br} / \mathrm{Cl}$ ratios (Table 4) and the $\mathrm{SUVA}_{254}$ values of the NOM fractions (Table 2) shows that Fraction 2, which had the lowest $\mathrm{SUVA}_{254}$ value also had the highest $\mathrm{Br} / \mathrm{Cl}$ ratio; while the opposite is true for Fraction 3. This suggests that the aromatic character of NOM could also influence the incorporation of bromine into DBPs. Liang and Singer (2003) reported that $\mathrm{HOBr}$ is more reactive towards aliphatic structures than aromatic structures in NOM. This is consistent with the data obtained in this study, where the fraction with the least aromatic character, possibly containing more aliphatic than aromatic organic materials, had the highest $\mathrm{Br} / \mathrm{Cl}$ ratio. Furthermore, the aromatic character of NOM has been shown to be a function of its MW. Previous studies have reported that NOM with MW of $1-10 \mathrm{kDa}$ have higher aromaticity than other fractions since they mainly consists of humic substances that are rich in aromatic functional groups (Allpike et al., 2005; Chow et al., 2005). NOM with MW greater than $10 \mathrm{kDa}$ has been associated with polysaccharide- and protein-like materials having lower aromatic character than humic substances (Chow et al., 2005). This is consistent with the observation made in this study, where Fraction 2 , which contained NOM with MW larger than $20 \mathrm{kDa}$, had the most aliphatic character among the MW fractions. Therefore, as well as the size of NOM, the structural characteristics of NOM (i.e. aromatic $v s$. aliphatic) also influence the incorporation of bromine into DBPs.

\section{CONCLUSIONS}

The smaller apparent MW fractions of NOM were found to produce significant amounts of DBPs, and the presence of bromide ion was found to affect the species distribution of DBPs, favouring the formation of brominated DBPs. NOM fractions that had less aromatic character and smaller MW were found to be more reactive towards bromine. Since toxicological studies have indicated that brominated DBPs are more harmful than their chlorinated analogues, the presence of bromide ion in drinking water sources need to be carefully considered in efforts to minimise the health risks associated with DBPs. Conventional water treatment processes are generally effective in removing the high MW fractions of NOM that are rich in aromatic structures, but do not remove bromide ion. It is important to remove the bulk of the DBP precursors, however, considering that the lower MW fractions of NOM produce significant amount of DBPs, with a higher relative contribution from brominated DBPs, water treatment processes need to be optimised for either bromide removal or aliphatic, low MW NOM removal, in order to minimise the risk of exposure to DBPs. The knowledge gained from this study will guide water utilities towards optimisation of their water treatment processes to maximise the removal of NOM fractions that contain significant precursors of DBPs.

\section{ACKNOWLEDGEMENTS}

The authors would like to acknowledge the Water Corporation, the CSIRO Water for a Healthy Country Flagship, and the ARC for funding various parts of this work. Support from other research staff at the Curtin Water Quality Research Centre is also acknowledged.

\section{REFERENCES}

Allpike, B. P., Heitz, A., Joll, C. A., Kagi, R. I., Abbt-Braun, G., Frimmel, F. H., Brinkmann, T., Her, N. and Amy, G. L. (2005). Size exclusion chromatography to characterise DOC removal in drinking water treatment. Environmental Science and Technology, 39, 2334-2342.

Aoustin, E., Schäfer, A. I., Fane, A. G. and Waite, T. D. (2001). Ultrafiltration of natural organic matter. Separation and Purification Technology, 22-23, 63-78. 
Bull, R. J. (2003). Are there significant health effects associated with the use of chemical disinfection of drinking water? M. Sinclair (Ed.), Report on DBPs and Health Effects Seminar and Workshop, CRC for Water Quality and Treatment, Melbourne, Victoria, Australia. http://www.waterquality.crc.org.au/publications/Occpaper05_info.htm

Chow, A. T., Gao, S. and Dahlgren, R. A. (2005). Physical and chemical fractionation of dissolved organic matter and trihalomethane precursors: A review. Journal of Water Supply: Reaserch and Technology AQUA, 54, 475-507.

Chow, C. W. K., van Leeuwen, J. A., Drikas, M., Fabris, R., Spark, K. M. and Page, D. W. (1999). The impact of the character of natural organic matter in conventional treatment with alum. Water Science and Technology. 40 (9), 97-104.

Croué, J.-P., Debroux, J.-F., Amy, G. L., Aiken, G. R. and Leenheer, J. A. (1999). Natural organic matter: Structural characteristics and reactive properties. In: Formation and Control of Disinfection By-Products in Drinking Water, P. C. Singer (ed.), American Water Works Association, Denver, Colorado, USA, pp. 65-93.

Drikas, M., Chow, C. W. K. and Cook, D. (2003). The Impact of recalcitrant organic character on disinfection stability, trihalomethane formation and bacterial regrowth: An evaluation of magnetic ion exchnage (MIEX) and alum coagulation. Journal of Water Supply: Reaserch and Technology AQUA, 52 (7), 475-487.

Glezer, V., Harris, B., Tal, N., Iosefzon, B. and Lev, O. (1999). Hydrolysis of haloacetonitriles: Linear free energy relationship, kinetics, and products. Water Research, 33, 1938-1948.

Hem, L. and Efraimsen, H. (2001). Assimilable carbon in molecular weight fractions of natural organic matter. Water Research, 35 (4), 1106-1110.

Hua, G. and Reckhow, D. A. (2007). Characterisation of disinfection byproduct precursors based on hydrophobicity and molecular size. Environmental Science and Technology, 41, 3309-3315.

Ichihashi, K., Teranishi, K. and Ichimura, A. (1998). Brominated trihalomethane formation in halogenation of humic acid in the coexistence of hypochlorite and hypobromite ions. Water Research, 33, 477-483.

Krasner, S. W. (1999). Chemistry of disinfection by-product formation. In: Formation and Control of Disinfection By-Products in Drinking Water, P.C. Singer (ed.), American Water Works Association, Denver, Colorado, USA, pp. 27-51.

Liang, L. and Singer, P. C. (2003). Factors influencing the formation and relative distribution of haloacetic acids and trihalomethanes in drinking water. Environmental Science and Technology, 37, 2920-2928.

Newcombe, G., Drikas, M., Assemi, S. and Beckett, R. (1997). Influence of characterised natural organic material on activated carbon adsorption: I. Characterisation of concentrated reservoir water. Water Research, 31 (5), 965-972.

Nieuwenhuijsen, M. J., Toledano, M. B., Eaton, N. E., Elliott, P. and Fawell, J. (2000). Chlorination disinfection by-products in water and their association with adverse reproductive outcomes: A 
review. Occupational Environmental Medicine, 57, 73-85.

Obolensky, A. and Singer, P. C. (2005). Halogen substitution patterns among disinfection byproducts in the Information Collection Rule database. Environmental Science and Technology, 39, 2719-2730.

Pelekani, C., Newcombe, G., Snoeyink, V. L., Hepplewhite, C., Asemi, S. and Beckett, R. (1999). Characterisation of natural organic matter using high performance size exclusion chromatography. Environmental Science and Technology, 33, 2807-2813.

Peuravuori, J. and Pihlaja K. (2004). Preliminary study of lake dissolved organic matter in light of nanoscale supramolecular assembly. Environmental Science and Technology, 38, 5958-5967.

Plewa, M. J., Wagner, E. D., Jazwierska, P., Richardson, S. D., Chen, P. H. and McKague, A. B. (2004). Chemical and biological characterisation of newly discovered iodoacid drinking water disinfection byproducts. Environmental Science and Technology, 38, 4713-4722.

Reckhow, D. A. and Singer, P. C. (1990). Chlorination by-products in drinking waters: From formation potentials to finished water concentrations. Journal American Water Works Association, 82, 173-180.

Richardson, S. D., Plewa, M. J., Wagner, E. D., Schoeny, R. and DeMarini, D. M. (2007). Occurrence, genotoxicity, and carcinogenicity of regulated and emerging disinfection by-products in drinking water: A review and roadmap for research. Mutation Research, 636, 178-242.

Roberts, M., Singer, P. C. and Obolensky, A. (2002). Comparing total HAA and total THM concentrations using ICR data. Journal American Water Works Association, 94, 103-114.

Sweetman, J. A. and Simmons, M. S. (1980). The production of bromophenols resulting from the chlorination of waters containing bromide ion and phenol. Water Research, 14, 287-290.

Villanueva, C. M., Cantor, K. P., Grimalt, J. O., Malats, N., Silverman, D., Tardon, A., GarciaClosas, R., Serra, C., Carrato, A., Castano-Vinyals, G., Marcos, R., Rothman, N., Real, F.X., Dosemeci, M. and Kogevinas, M. (2007). Bladder cancer and exposure to water disinfection byproducts through ingestion, bathing, showering, and swimming in pools. American Journal of Epidemiology, 165, 148-156.

Westerhoff, P., Chao, P. and Mash, H. (2004). Reactivity of natural organic matter with aqueous chlorine and bromine. Water Research, 38, 1502-1513. 